Images in...

\title{
Thrombosed prosthetic mitral valve
}

\author{
Komarakshi Balakrishnan, ${ }^{1}$ Sanjeev Aggarwal, ${ }^{2}$ Gautam Balakrishnan ${ }^{3}$ \\ ${ }^{1}$ Cardiothoracic Surgery Department, Fortis Malar Hospital, Chennai, India; \\ ${ }^{2}$ Cardiology Department, Fortis Malar Hospital, Chennai, India; \\ ${ }^{3}$ Internal Medicine Department, Fortis Malar Hospital, Chennai, India
}

Correspondence to Dr Komarakshi Balakrishnan, krbalakrishnan@vsnl.com

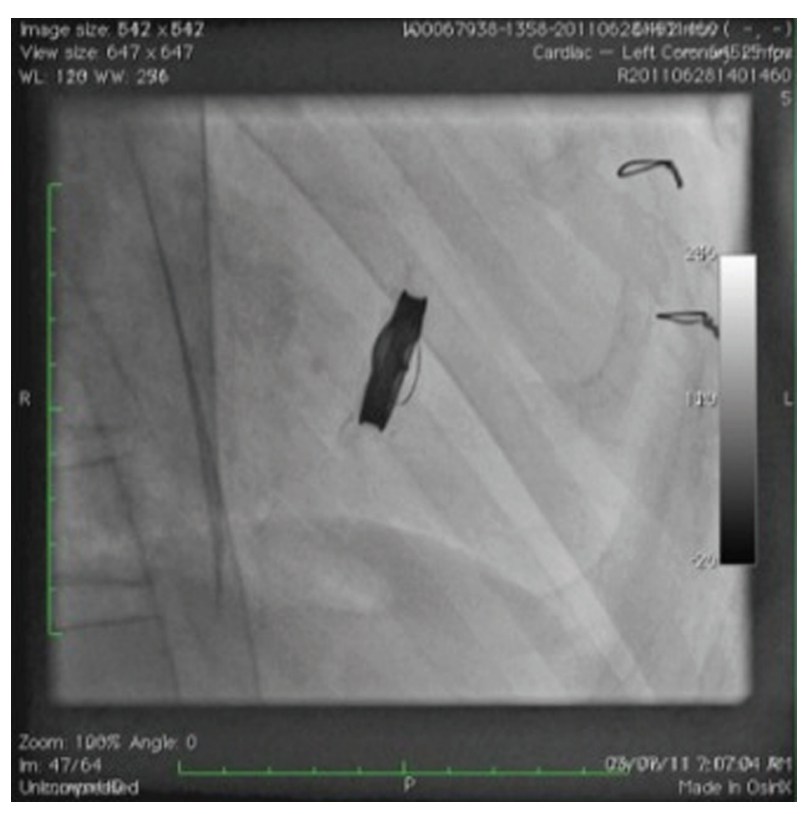

Figure 1 The incomplete closure of the valve disc during systole is evident.

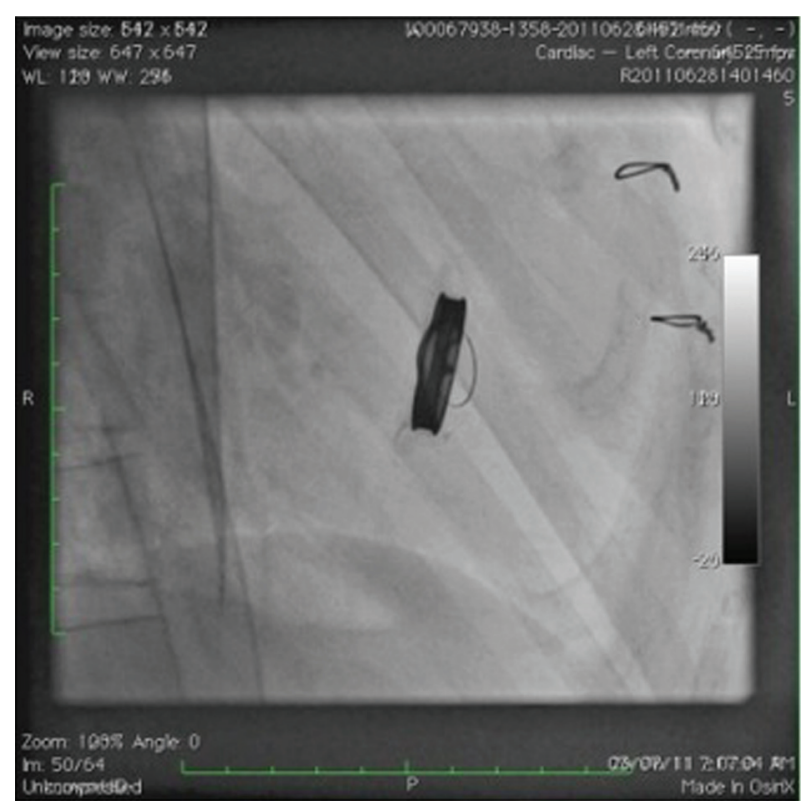

Figure 2 Disc position in diastole. The disc opening is limited, with an 'opening angle' of barely $15^{\circ}$ resulting in severe prosthetic stenosis.

\section{DESCRIPTION}

A 29-year-old woman presented with pulmonary oedema and low cardiac output. Her mitral valve was replaced 20 years back with a Sorin mechanical valve. She had stopped anticoagulants a month back on her own for excessive menstrual bleeding. Echo showed a gradient of $26 \mathrm{~mm} \mathrm{Hg}$ across the valve with regurgitation. Fluroscopy confirmed limited disc opening of only $15^{\circ}$ with incomplete disc closure (figures 1 and 2) (videos 1 and 2). She was reoperated using a St Jude mechanical valve. The excised prosthetic valve showed thrombus and pannus almost completely occluding the disc and severely restricting disc mobility (figures 3 and 4).

Video 1 The minimal opening and incomplete closure of the disc are obvious.10.1136/bcr.10.2011.5002v1

Video 2 Enface view showing minimal disc excursion.10.1136/ bcr.10.2011.5002v2

Acknowledgements The authors wish to acknowledge Drs Suresh Rao, NK Kapadia, SK Chowdhry and Vijit Cherian for contributing to the clinical care of this patient.

Competing interests None.

Patient consent Not obtained.

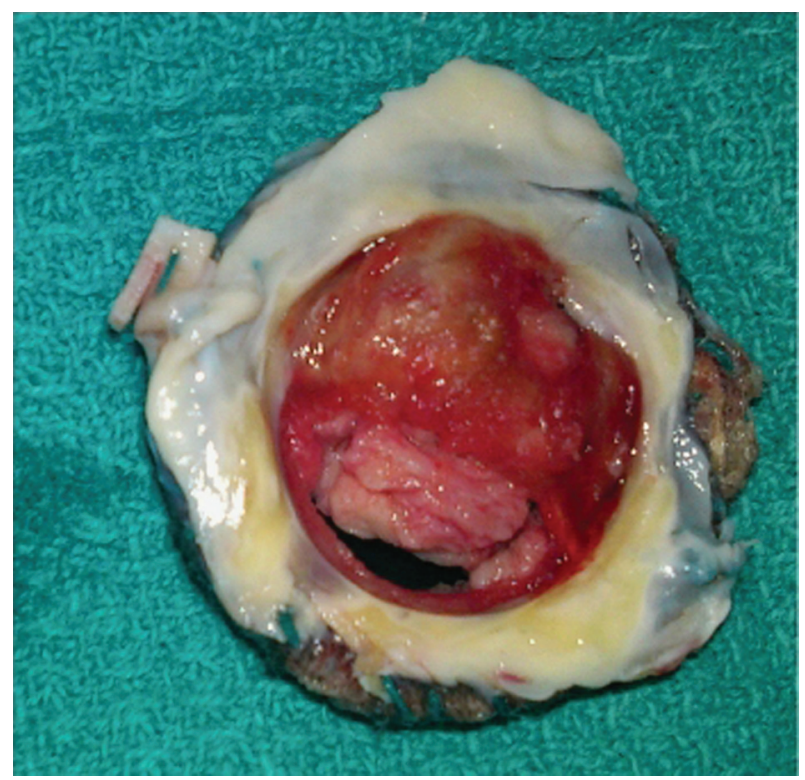

Figure 3 The prosthesis, viewed from the atrial side is almost completely occluded by thrombus and pannus. 


\section{BMJ Case Reports}

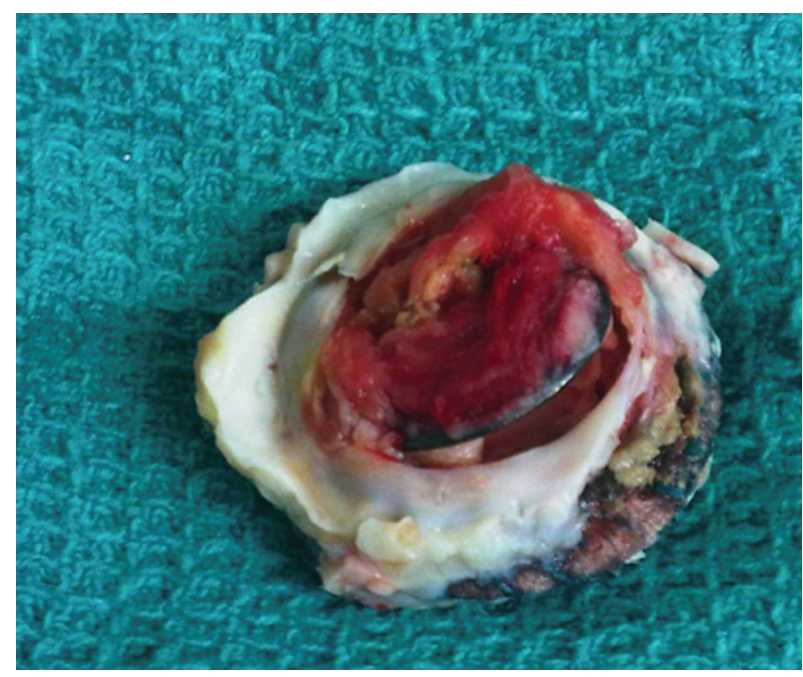

Figure 4 Seen from the ventricular side, the disc is clearly entrapped preventing it from closing completely. This is clearly seen in the fluoroscopy and is the reason for the mitral incompetence.

This pdf has been created automatically from the final edited text and images.

Copyright 2012 BMJ Publishing Group. All rights reserved. For permission to reuse any of this content visit http://group.bmj.com/group/rights-licensing/permissions.

BMJ Case Report Fellows may re-use this article for personal use and teaching without any further permission.

Please cite this article as follows (you will need to access the article online to obtain the date of publication).

Balakrishnan K, Aggarwal S, Balakrishnan G. Thrombosed prosthetic mitral valve. BMJ Case Reports 2012;10.1136/bcr.10.2011.5002, Published XXX

Become a Fellow of BMJ Case Reports today and you can:

- Submit as many cases as you like

- Enjoy fast sympathetic peer review and rapid publication of accepted articles

- Access all the published articles

- Re-use any of the published material for personal use and teaching without further permission

For information on Institutional Fellowships contact consortiasales@bmjgroup.com

Visit casereports.bmj.com for more articles like this and to become a Fellow

Keep up to date with all published cases by signing up for an alert (all we need is your email address) http://casereports.bmj.com/cgi/alerts/etoc 